\title{
ШЛЯХИ ФОРМУВАННЯ ГОТОВНОСТІ МАЙБУТНІХ УЧИТЕЛІВ ДО УПРАВЛІННЯ САМОСТІЙНОЮ РОБОТОЮ УЧНІВ
}

У статті розкрито підходи, виокремлено шллхи формування готовності майбутніх учителів до управління
самостійною роботою учнів у процесі професійної підготовки, подано зміст і структуру цього складного особистісного утворення.

Ключові слова: професійна готовність, самостійна робота.

В статье раскрываются подходы, выделяются пути формирования готовности будущих учителей в управлении самостоятельной работой учеников в прочессе профессиональной подготовки, подается содержание и структура этого сложного личностного образования.

Ключевые слова: профессиональная готовность, самостоятельная работа.

In article approaches reveal, ways of formation of readiness of the future teachers to management of independent work of pupils in the course of vocational training are allocated, the content and structure of this difficult personal formation moves.

Key words: professional readiness, independent work.

У сучасних умовах, коли школа покликана забезпечити сприяння соціалізації особистості, нагальними цілями професійно-педагогічної підготовки стає формування готовності майбутніх учителів до наукового управління навчально-виховним процесом, становлення в них позиції суб'єкта управління.

Управління сьогодні виокремлюється на перший план професійної компетентності сучасного вчителя, є іï провідним складником, що забезпечує процеси особистісного розвитку в навчанні й характеризує вчителя-управлінця, здатного в сучасних умовах масового навчання створювати можливості для індивідуального особистісного розвитку учнів.

Необхідність підготовки педагогічних кадрів нового типу, яка відповідає високим вимогам суспільства й сучасної педагогічної науки, що динамічно змінюються й розвиваються, наголошується у працях Ф. Гоноболіна, К. Ссипович, І. Зимньої, П. Кандибович, Л. Кондрашової, В. Крутецького, А. Маркової, В. Сластьоніна, Л. Хомич та ін.

У такому напрямку дослідження важливими є роботи, які розкривають зміст готовності педагога до певного аспекту професійної діяльності чи комплексного ії здійснення (В. Беспалько, Т. Іванова, К. Дурай-Новакова, М. Дьяченко, Д. Узнадзе та інші). Актуальність педагогічного управління як важлива функція сучасного вчителя показана в роботах Т. Давиденко, Г. Сльникової, Ю. Конаржевського, В. Лазарева, В. Пикельної, М. Поташника, Н. Тализіної, Т. Шамової та багатьох інших. Інтерес складає співвіднесення функцій і засобів педагогічного управління та загальних теорій соціального управління, розроблених П. Друкером, Ф.Тейлором, А. Файолем та іншими.

Методологія організації самостійної роботи тих, хто навчається, знайшла відображення в дослідженнях відомих вітчизняних учених: В. Беспалька, В. Бондаря, В. Буряка, Л. Вяткіна, Б. Ссипова， Л. Жарової， О. Кірсанова， М. Махмутова， П. Підкасистого， О. Савченко та багатьох інших.

Метою статті є виокремлення шляхів формування готовності майбутніх учителів до управління самостійною роботою учнів у процесі професійної підготовки.

Філософський словник тлумачить «управління» як елемент, функцію організованих систем різної природи (біологічних, соціальних, технічних), що забезпечує збереження їхньої певної структури, підтримку режиму діяльності, реалізацію програми, мети діяльності [6].

У широкому змісті управління $є$ регулюванням стану якої-небудь системи з метою одержання потрібного результату. Соціальне управління, до якого належить і педагогічне, $\epsilon$, передусім, усвідомленою діяльністю людини, яка має певну мету. I не просто діяльністю, а тим іії особливим різновидом, який пов'язаний із виробленням, виконанням, організацією, спрямованою на втілення виконання в життя, із спрямуванням системи до відповідної заданої мети, підбиттям підсумків діяльності, систематичним отриманням, переробкою та використанням інформації (В. Афанасьєв). Педагогічне управління в цій структурі вирізняється своїми об'єктами, а також характером, обумовленим специфікою педагогічних наук [5].

Проблема управління самостійною роботою учнів порушує цілу низку питань, що належать до готовності самого вчителя як суб'єкта управлінської діяльності.

У світлі сучасних наукових уявлень «готовність» до того або того виду діяльності визначається як мобілізація всіх психічних і фізичних систем людини, як системне відображення особистісних якостей, необхідних для успішного й ефективного виконання цієї діяльності.

На основі аналізу численної літератури І. Бєлякова з'ясовує готовність майбутнього вчителя до педагогічної діяльності як певний стан, у якому можна виокремити особистісний, науковотеоретичний і практичний компоненти, а готовність майбутнього вчителя до управління самостійною 
роботою учнів як складне цілісне утворення, що включає особистісну, науково-теоретичну, практичну готовність при провідній ролі особистісної готовності [1].

Особистісна готовність у цьому контексті $є$ особистісною сутністю майбутнього вчителя людини, життєві цінності якої пов'язані з прагненням до ефективної організації навчально-виховної діяльності. І від того, як розвинені його певні особистісні якості, якими є його особистісні ставлення й намагання, багато в чому залежить успіх його педагогічної праці.Отже, зміст особистісної готовності майбутнього вчителя до управління самостійною роботою учнів $\epsilon$ інтегральною єдністю позитивного, відповідального й творчого ставлення до цього виду діяльності [1].

Практична готовність майбутнього вчителя до управління самостійною роботою учня передбачає такі важливі уміння, як-от: визначати загальні, практичні, виховні й розвивальні цілі управління; здійснювати поетапне управління самостійною роботою учнів з урахуванням іiї якісної своєрідності; ураховувати індивідуально-психологічні особливості учнів і рівень їх навченості, позицію в навчальному процесі, ступінь самостійності; практично застосовувати засоби управління; здійснювати педагогічну підтримку самостійної роботи; контроль діяльності учнів і самоконтроль власних управлінських дій [1].

Зміст науково-теоретичної готовності складають знання й розуміння сутності та значення самостійної роботи в навчальному процесі, методики управління самостійною роботою учнів, їі різновидів, типології, методів і форм, співвідношення видів управління з видами самостійної роботи.

Особливе значення для становлення досліджуваної готовності має розуміння педагогом сутності самостійної роботи, як роботи, що виконується поза прямою участю вчителя, але під його безпосереднім керівництвом й у спеціально відведений час, при цьому учні свідомо прагнуть досягти пізнавальної мети, виявляючи свої вміння й виражаючи в тій або іншій формі результати своїх розумових і фізичних дій [2].

Орієнтуючись на цей підхід, майбутній учитель має усвідомити ті ознаки, які характеризують самостійну роботу учнів: 1) відсутність безпосередньої участі вчителя в роботі; 2) опосередковане керівництво, що виражається в постановці завдання, наданні допомоги й здійсненні контролю, а також у підготовці спеціальних дидактичних засобів; 3) виконання в спеціально відведений час; 4) установлення самими учнями ритму роботи й дозування часу на розв'язання поставлених завдань; 5) особливий характер діяльності учнів, зокрема свідоме ставлення до досягнення поставленої перед ними мети [2].

Виходячи 3 цього, необхідним є засвоєння студентами засад методичного управління самостійною роботою студентів. К. Ссипович під методичним управлінням розуміє «системне, інтегральне, багаторівневе, адаптивне утворення, що володіє стійкою сукупністю провідних ознак і займається цілеспрямованим проектуванням педагогічного, психологічного забезпечення навчального процесу певної предметної галузі з урахуванням її якісної своєрідності з метою гарантованого досягнення із заздалегідь заданою надійністю результатів навченості кожного учня засобами досліджуваного конкретного предмета» [3, с. 60]. Предметом методичного управління $\epsilon$ пізнавальна діяльність учнів у ході самостійної роботи, а також засоби опосередкованого управління, якими $є$ роздавальний матеріал, дидактичні засоби навчання, ТЗН.

Вивчення проблеми управління в навчанні дозволяє зробити висновок про те, що воно, за умови правильного його розуміння, здатне реалізувати стратегію розвитку особистості учня в пізнавальній діяльності та самоосвіті.

Циклом методичного управління, за К. Єсипович, є обмежене в часі, повторювальне явище, а блоком методичного управління - одиниця структурно-функціонального характеру, засіб здійснення функціонального моделювання досліджуваних об'єктів управління на рівні навчальних процесів. Учений виокремлює 9 блоків циклу методичного управління, що виражає замкнений цикл управління як діяльності: 1) блок визначення цілей управління; 2) обліку якісної своєрідності формованої діяльності; 3) мотиваційного забезпечення процесу управління; 4) організації зворотного зв'язку; 5) організації контролю 6) самоконтролю; 7) обліку індивідуальних особливостей учнів; 8) організації навчального процесу з оволодіння об'єктами управління; 9) блок корекції [3, с. 34-37].

Розглядаючи проблему підготовки майбутнього вчителя, досить часто на перший план науковці ставлять питання формування готовності до організації тієї чи іншої діяльності учнів. Разом із цим, сьогодні цього не достатньо. Організація є лише однією з управлінських дій, поряд із плануванням та контролем, і не забезпечує динамічного й керованого розвитку готовності майбутнього вчителя. Останнє диктує необхідність розгляду процесу формування професійної готовності майбутнього вчителя через реалізацію сукупності визначених функцій.

Серед розмаїття функцій методичного управління, у контексті становлення готовності вчителя до управління самостійною роботою учнів, виокремлюють такі:

- функція прогнозування, що реалізовується майбутнім учителем у процесі розв'язання ним завдань стратегічного, тактичного, операційного характеру під час професійної підготовки;

- функція планування, яке здійснюється за допомогою опрацювання різних видів планів (самостійної роботи, навчальної діяльності, науково-дослідної діяльності тощо), які визначаються в наукові літературі як інструмент цілеспрямованого впливу на процес навчання; 
- функція вироблення й прийняття рішень, що пов'язана 3 необхідністю розв'язання різних управлінських завдань, як частини педагогічних: серед них: діагностувальні, пошукові, навчальні, організаторські, контролюючі управлінські завдання, які необхідно вміти вирішувати майбутньому вчителеві на різних етапах управління процесом навчання. При цьому майбутній учитель переходить від зовнішньої регуляції своїх дій до саморегуляції через послідовне проходження орієнтовної, виконавської й контрольно-оцінної фаз пізнавальної діяльності;

функція організації, яка реалізується через організаторські вміння викладача в процесі з'ясування управлінських завдань на різних етапах формування необхідної готовності в майбутніх учителів;

функція обліку, контролю й регулювання самостійної роботи, що пов'язана 3 контролем формованої діяльності, здійснюваним різними методами, й спрямована на забезпечення мотиваційного зросту майбутнього вчителя, забезпечення раціональної погодженості дій суб’єктів і об’єктів управління в процесі формування досліджуваної готовності [1].

Окреслені функції управління універсальні за своїм призначенням і можуть бути реалізовані в ході формування готовності до управління різновидами навчально-пізнавальної діяльності учнів і при цьому носять комплексний характер. Важливою є реалізація сукупності функцій управління в процесі професійної підготовки майбутнього вчителя, що забезпечує управлінський підхід до формування готовності шляхом залучення студентів до професійно орієнтованої діяльності. У випадку становлення готовності до управління самостійною роботою такою діяльністю $є$ виконання самостійної роботи репродуктивного, продуктивного й творчого рівнів [1].

Процес формування готовності майбутнього вчителя до управління самостійною роботою учнів включає низку етапів, необхідних і достатніх для здійснення повноцінного процесу формування етапи прогнозування, планування, цілепокладання, організації, зворотного зв’язку, контролю, корекції. При цьому управління має властивість циклічності, що забезпечує процес постійного розвитку й удосконалення професійної готовності майбутнього вчителя [4].

Процес формування необхідної готовності забезпечується комплексом педагогічних умов, що створюються в процесі професійної підготовки. Ці умови повинні забезпечити становлення суб'єкта управління з високим рівнем самостійності управлінської діяльності, що, у свою чергу, уможливлює високий рівень управлінських знань і вмінь, готовність приймати рішення й відповідати за їхнє виконання, здатність до творчості й творення, мобільність й автономність особистості майбутнього вчителя.

У процесі професійної підготовки мають бути створені умови, за яких відбувається повноцінне різнобічне формування всіх складових готовності до управління самостійною роботою учнів особистісної, науково-теоретичної й практичної.

Управління процесом формування особистісної складової досліджуваної готовності потребує застосування особистісно зорієнтованих підходів у професійній підготовці майбутнього вчителя, які наголошують на особистісній значущості навчання, його продуктивності, сприяють ефективному становленню особистісних якостей учителя-керівника, його управлінських знань і вмінь.

Особистісно зорієнтований підхід має наскрізним чином пронизувати зміст професійної підготовки майбутнього вчителя, актуалізовуватися в ході засвоєння дисциплін суспільногуманітарної і психолого-педагогічної спрямованості, мати місце під час безперервної педагогічної практики, стати предметом осмислення під час науково-дослідної роботи студента.

Становлення науково-теоретичної готовності відбувається через засвоєння студентами базових категорій дидактики, спеціальних методик i теорії управління, а в магістратурі - педагогічного менеджменту.

Засвоєння та творче перероблення опорних знань під час обговорення проблемних питань організації та управління самостійною роботою учнів на семінарах і практикумах, проблемних лекціях повинні стати тим підгрунтям, на якому будуть формуватися важливі уміння та навички, управлінська компетентність майбутнього вчителя.

Практична готовність до управління самостійною роботою учнів передбачає, передовсім, набуття безпосереднього досвіду управління й самоуправління різнорівневою й різноманітною самостійною роботою, з усіма можливими засобами ії здійснення. Цей аспект готовності не може бути наданий студентові в готовому вигляді, а передбачає копітку роботу 3 формування необхідних умінь та навичок, досвіду самостійної діяльності й управління нею. Важливе значення має включення студентів у навчально-виховний процес школи під час педагогічних практик і в ході дослідноекспериментальної роботи.

Отже, будь-який процес навчання й тісно пов'язаний 3 ним процес формування необхідно розглядати як керований, а проблеми становлення складників професійної готовності майбутнього вчителя розв'язувати через побудову системи управління його професійно зорієнтованою діяльністю.

Готовність майбутнього вчителя до управління самостійною роботою учнів розглядаємо як готовність суб'єкта управління, що передбачає високий рівень самостійності управлінської діяльності й забезпечується високим рівнем управлінських знань і вмінь, компетентності, готовністю приймати рішення й відповідати за їхнє виконання, здатністю до творчості й творення, мобільністю й 
автономністю особистості майбутнього вчителя. Зміст цієї готовності передбачає особистісну, науково-теоретичну і практичну готовність.

Процес управління формуванням готовності майбутніх учителів має реалізовувати важливі функції, здійснюватися поетапно i враховувати циклічність у становленні цього важливого особистісного утворення, що у свою чергу, забезпечує ефективність і успішність процесу.

Зазначене вище не вичерпує проблеми формування готовності майбутнього вчителя до управління самостійною роботою учнів і потребує дослідження механізмів, створення модельного уявлення цілісної структури професійної готовності.

\section{Література}

1. Белякова И. В.Формирование готовности будущего учителя к управлению самостоятельной работой учащихся: дис. ... канд. пед. наук: 13.00 .08 / Белякова Ирина Вячеславовна. - Магнитогорск, 2004. - 195 с. 2. Есипов Б. П. Самостоятельная работа учащихся в процессе обучения / Борис Петрович Есипов. - М. : Изд-во АПН РСФСР, 1961. - Вып. 115. - С. 5-37. 3. Есипович К. Б. Управление познавательной деятельностью учащихся при изучении иностранных языков в средней школе / К. Б. Есипович. - М. : Просвещение, 1988. 190 с. 4. Сльникова Г. Управлінська компетентність / Галина Єльникова. - К. : Ред. загальнопед. газ., 2005. 128 с. 5. Мармаза О. І. Менеджмент в освіті: дорожня карта керівника / Олександра Іванівна Мармаза. - Х. : Основа, 2007. - 448 с. 6. Философский словарь / [ред. И. Т. Фролова].- М. : Политиздат, 1987. - [5-е изд.]. $590 \mathrm{c}$. 